\title{
Genotype $\times$ Season Interaction for Time to Flowering and Flower and Plant Diameter in Exacum affine Balf.
}

\author{
David B. Rubino \\ U.S. Department of Agriculture, Agricultural Research Service, Florist and \\ Nursery Crops Laboratory, Beltsville, MD 20705-2350
}

Additional index words. Persian violet, flower breeding

\begin{abstract}
Genotype $\times$ season interaction was investigated for days to first flower and full bloom and flower and plant diameter for 15 exacum cultivars and breeding lines produced in two glasshouses during winter and summer growing seasons. Genotype $\mathrm{x}$ season interactions were significant $(P<0.01)$ for all four characteristics. Genotype rankings for time to flowering and plant diameter varied greatly depending on the growing season; evaluation during the target growing season is recommended when selecting among exacum genotypes for these characteristics.
\end{abstract}

In plant improvement programs, the amount of genotypic variance due to genotype $\mathrm{x}$ environment interaction determines whether genotypes are tested in multiple environments (Comstock and Moll, 1963). Research on many field crops has demonstrated that genotype $\mathrm{x}$ environment interaction is significant for some characteristics (Chakrown et al., 1990; Fernandez and Chen, 1989; Shellie and Hosfield, 1991). Although floricultural crop breeders usually test genotypes under multiple environments, few genotype $x$ environment interaction studies have been conducted.

For Gerbera hybrida cut flower yield, Byrne et al. (1987) reported that selection response will be overestimated if genotype $\mathrm{x}$ environment interaction is not taken into account when estimating heritability. In addition, Teynor et al. (1989a, 1989b) found that chrysanthemum [Dendranthema $\times$ grandiflorum (Ramat.) Kitamura] clone flower color could be classified differently depending on environment (field and glasshouse); thus, they recommended evaluating flower color under multiple environments.

Breeding programs have improved exacum (a flowering, potted plant) growth habit and time to flowering (Harbaugh, 1991; Irwin,

Received for publication 7 Feb. 1992. Accepted for publication 12 Nov. 1992. Suzy Flowers provided excellent technical support. Germplasm for this investigation was provided by J \& L Plants, Amarillo, Texas; Earl J. Small Growers, Pinellas Park, Fla.; and Rosendals EX-PLANTS Aps., Assens, Denmark. I gratefully acknowledge the financial assistance of the Fred C. Gloeckner Foundation. Marla McIntosh, Professor, Dept. of Agronomy, Univ. of Maryland, College Park, provided statistical consultation. Mention of a trade name or proprietary product does not constitute a guarantee or warranty by the U.S. Dept. of Agriculture and does not imply approval to the exclusion of other products that also may be suitable. The cost of publishing this paper was defrayed in part by the payment of page charges. Under postal regulations, this paper therefore must be hereby marked advertisement solely to indicate this fact.
1984; Wolf and Craig, 1988), although further improvements are desired. Research on the environmental effects on these characteristics so far has focused on one or a few genotypes. For two inbred exacum lines, Williams et al. ( 1983) reported that irradiance level influences foliar characteristics and the number of days to flowering. They suggested that the response to irradiance level explained the seasonal variation in exacum flowering time. Supplemental irradiance $\left(30 \mathrm{~W} \cdot \mathrm{m}^{-2}\right)$ during winter also reduced the production period of 'Best Blue' exacum (Andersen and Aabrandt, 1988). In addition, Harbaugh and Waters (1982) reported that fertilizer rate influenced foliar chlorosis and floral display ratings of 'Elfin' exacum plants in low-irradiance, simulated home conditions.

Although seasonal variations in exacum flowering time and morphological characteristics have beennoted (Larson, 198 1; Williams et al., 1983), the importance of the interaction between exacum genotype and growing season has not been reported. Therefore, the objective of this investigation was to determine the importance of the genotype $\mathrm{x}$ season interaction for days to first flower and full bloom and flower and plant diameter in exacum in winter and summer growing seasons.

The experiment with 15 exacum genotypes (cultivars and breeding lines) (Table 1) was conducted from Oct. 1989 through June 1990 (winter environment) and Feb. through Sept. 1990 (summer environment). Genotypes were grown in two glasshouses in each season. For winter, temperatures averaged $17 \mathrm{C}$ in one glasshouse and $19 \mathrm{C}$ in the other; for summer, temperatures averaged $22 \mathrm{C}$ in both glasshouses.

About 14 weeks after seeds were sown, seedlings of each genotype were planted, one per 1.05-liter pot, in a soilless medium (Pro-mix BX; Premier Brands, Stamford, Conn.) supplemented with $80 \mathrm{~g}$ of a fritted micronutrient mixture/ $\mathrm{m}^{3}$ (Micromax; Sierra Chemical, Milpitas, Calif.) and $2 \mathrm{~g}$ of Osmocote 14N-6.1P-11.6K (controlled-release fertilizer) per pot. Standard cultural practices were used (Irwin, 1984). Genotypes were arranged in a split plot (in time) in a randomized completeblock design at a density of 27 pots $/ \mathrm{m}^{2}$, two blocks per glasshouse, at Beltsville, Md.

Five plants that were surrounded by competitive plants were evaluated for each genotype in each block. The number of days to the opening of the first flower and full bloom $(\approx 25 \%$ of-the plant canopy covered with flowers) was recorded. At full bloom, flower (an average of measurements made on three flowers) and plant (an average of the two widest measurements) diameters were recorded.

Data were averaged over the five plants for analysis of variance. Seasons and genotypes we reconsidered fixed effects, and glasshouses and blocks were considered random effects. If nonsignificant $(\mathrm{P} \leq 0.05)$, interactions involving glasshouses were pooled with error terms.

Differences between growing season were significant for flower diameter but not for the other three characteristics (Table 1). Average flower diameter for each genotype was smaller in summer than in winter (Table 2).

For all four characteristics, variation due to glasshouses was nonsignificant, although variation among genotypes was highly significant $(P<0.01)$ (Table 1). Genotype 505 required an average of 30 days longer to reach full bloom than genotype CE (Table 2). However, genotype 505 had a larger average flower diameter than the other genotypes. This result suggests that genotype 505 may be polyploid (Erb et al., 1981; Semeniuk, 1978). Plant diameter ranged from an average of $245 \mathrm{~mm}$ for genotype CE to $\approx 283 \mathrm{~mm}$ for genotypes $42 \mathrm{E}$ and $42 \mathrm{Y}$ and cultivar Blue Champion.

Seasonal difference in time to flowering was absent when averaged over genotypes

Table 1. Mean squares from the combined analysis of variance for days to first flower and full bloom and flower and plant diameter for 15 exacum genotypes grown in two glasshouses during two seasons.

\begin{tabular}{|c|c|c|c|c|c|}
\hline \multirow[b]{3}{*}{ Source } & \multirow[b]{3}{*}{$\mathrm{df}$} & \multicolumn{2}{|c|}{ Days to } & & \\
\hline & & \multirow{2}{*}{$\begin{array}{l}\text { First } \\
\text { flower }\end{array}$} & \multirow{2}{*}{$\begin{array}{c}\text { Full } \\
\text { bloom }\end{array}$} & \multicolumn{2}{|c|}{ Diam } \\
\hline & & & & Flower & Plant \\
\hline Season & 1 & $420^{\mathrm{ws}}$ & $373^{\mathrm{Ns}}$ & $132.0^{* *}$ & $3818^{\mathrm{NS}}$ \\
\hline Glasshouse & 1 & $29^{\mathrm{Ns}}$ & $44^{\mathrm{Ns}}$ & $0.1^{\mathrm{NS}}$ & $648^{\mathrm{NS}}$ \\
\hline Error $^{2}(\mathrm{~A})$ & 5 & 358 & 461 & 0.8 & 743 \\
\hline Genotype & 14 & $609^{* *}$ & $594^{* *}$ & $12.4^{* *}$ & $1460^{* *}$ \\
\hline Genotype $\times$ season & 14 & $386^{* *}$ & $240^{* *}$ & $0.9^{* *}$ & $618^{* *}$ \\
\hline Error (B) & $83^{y}$ & 59 & 44 & 0.3 & 188 \\
\hline
\end{tabular}

${ }^{2}$ Interactions with glasshouses were not significant and were pooled with error terms.

y One degree of freedom was subtracted from Error (B) due to estimated values for one missing plot. ${ }^{\text {Ns, }}{ }^{* *}$ Nonsignificant or significant at $P=0.01$, respectively. 
BREEDING AND GENETICS

Table 2. Phenotypic means for days to first flower and full bloom and flower and plant diameter for 15 exacum genotypes grown during two seasons.

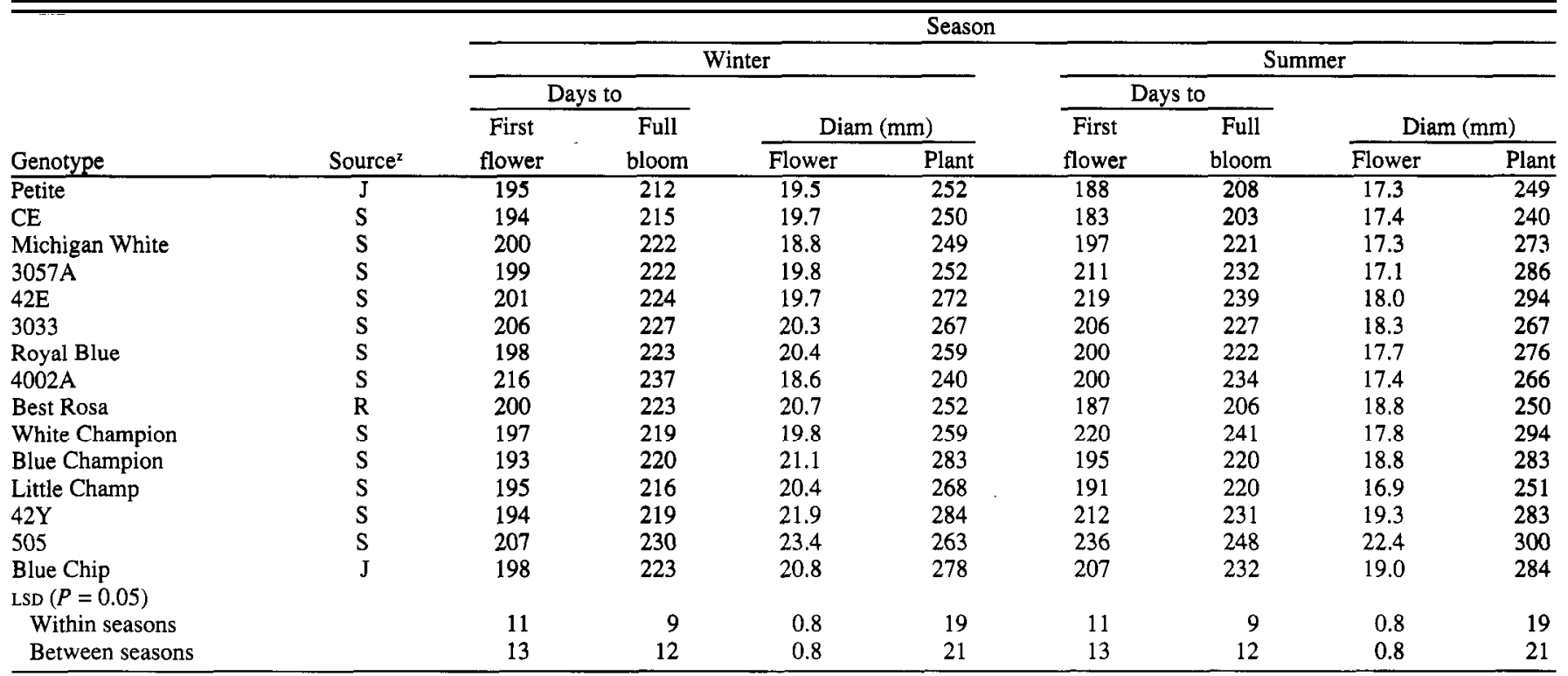

2J = J \& L Plants, Amarillo. Texas; S = Earl J. Small Growers, Pinellas Park, Fla.: R = Rosendals EX-PLANTS Aps., Assens, Denmark.

(Table 1). For some genotypes (e.g., CE), significantly fewer days to first flower and full bloom were required in summer than winter (Table 2). However, other genotypes (e.g., 42E) flowered earlier in winter than summer These differences are reflected in the significant genotype $\mathrm{x}$ season interaction for days to first flower and full bloom (Table 1). For days to first flower, the genotype $\mathbf{x}$ season mean square was $\approx 60 \%$ of that for genotypes. Genotype rank for days to first flower changed dramatically for some genotypes with growing season. For example, genotype $42 \mathrm{Y}$ was ranked second in winter but 12th in summer. Lower irradiance levels during winter may increase flower production time in exacum (Larson, 1981; Williams et al., 1983); however, the influence of various environmental factors may be genotype-dependent. There were also large changes in rank in winter vs. summer growing seasons for days to full bloom and plant diameter; these changes are reflected in highly significant genotype $\mathbf{x}$ season interactions (Table 1). For flower diameter, the mean square for genotype was 14 times larger than the mean square for genotype $\mathrm{x}$ season interaction. Nevertheless, the genotype $x$ season source of variation for flower diameter was highly significant (Table 1).

The exacum genotypes in this study interacted with growing season more than with glasshouse environment for days to first flower and full bloom and for flower and plant diameter. Therefore, time to flowering and flower and plant diameter should be evaluated in winter and summer if the objective is to select an early flowering genotype with a large flower and small plant diameter for a particular growing season.

A target environment for glasshouse floral crops can be. difficult to define, especially for those crops that are grown year-round under natural daylength and irradiance at a variety of latitudes. Further investigations are needed to examine the magnitude of the genotype $\mathrm{x}$ environment interaction for economic characteristics in a wide range of environments for all major floricultural crops. Evaluating genotypes in more than one environment was found to be important for Gerbera hybrida cut flower yield (Byrne et al., 1987) and chrysanthemum flower color (Teynor et al., 1989a, 1989b).This method also is recommended for evaluating exacum time to flowering and flower and plant diameter.

\section{Literature Cited}

Andersen, H. and Z. Aabrandt. 1988. Kunstlys til Exacum affine 'Best Blue'. Gartner Tidende 32:836-837.

Byrne, T., D. Drennan, and J. Harding. 1987. Genotype $\mathrm{x}$ environment interaction bias in heritability estimates for cut-flower yield of greenhouse gerberas. J. Amer. Soc. Hort. Sci. 112:724-727.

Chakrown, M., C.M. Taliaferro, and R.W. McNew. 1990. Genotype-environment interactions of bermudagrass forage yields. Crop Sci. 30:4953.

Comstock, R.E. and R.H. Moll. 1963. Genotypeenvironment interactions, p.164-196. In: W.D. Hanson and W.F. Robinson (eds.). Statistical genetics and plant breeding. Natl. Acad. Sci., Natl. Res. Council, Washington, DC. Publ. 982. Erb, W.A., R.P. Niedz, and R. Craig. 1981. Use of colchiploids in breeding Exacum affine Balf. HortScience 16:454. (Abstr.)

Fernandez, G.C.J. and H.K. Chen. 1989. Implications of year $\mathrm{x}$ season $\mathrm{x}$ genotype interactions in mungbean yield trials. J. Amer. Soc. Hort. Sci. 114:999-1002

Harbaugh, B.K. 1991. Essentials for quality exacum. Greenhouse Grower 9:82-85.

Harbaugh, B.K. and W.E. Waters. 1982. Influence of controlled-release fertilizer on Exacum affine Balf. F. 'Elfin' during production and subsequent simulated home conditions. HortScience 17:605-606.

Irwin, L. 1984. Exacum. Minnesota State Florists Bul. 33:8-9.

Larson, R.A. 1981. Commercial production of exacum. North Carolina Flower Growers Bul. 25:1-6.

Semeniuk, P. 1978. Colchiploidy in Exacum. J. Hered. 69:277-278.

Shellie, K.C. and G.L. Hosfield. 1991. Genotype × environmental effects on food quality of common bean: Resource-efficient testing procedures. J. Amer. Soc. Hort. Sci. 116:732-736.

Teynor, T.M., P.D. Ascher, R.E. Widmer, and J.J. Luby. 1989a. Inheritance of flower color in Dendranthema grandiflora Tzvelev. (Chrysanthemum morifolium Ramat.) using cultivars and inbreds. I. Plastid pigmentation. Euphytica 42:199-207.

Teynor, T.M., P.D. Ascher, R.E. Widmer, and J.J. Luby. 1989b. Inheritance of flower color in Dendranthema grandiflora Tzvelev. (Chrysanthemum morifolium Ramat.) using cultivars and inbreds. II. Vacuole pigmentation. Euphytica 42:297-305.

Williams, S., S. Wolf, and E.J. Holcomb. 1983. Growth and flowering of Exacum affine at three radiant energy levels. HortScience 18:366-367.

Wolf, S.J. and R. Craig. 1988. Inheritance of flower color in Exacum affine Balf. J. Hered. 79:303306. 